First Peoples Child \& Family Review

An Interdisciplinary Journal Honouring the Voices, Perspectives, and Knowledges of
First Peoples through Research, Critical Analyses, Stories, Standpoints and Media

Reviews

\title{
Editorial: Exploring Complexities in the Research Involving First Peoples Children, Families and Communities
}

\section{Marlyn Bennett}

Volume 6, Number 1, 2011

URI: https://id.erudit.org/iderudit/1068892ar

DOI: https://doi.org/10.7202/1068892ar

See table of contents

Publisher(s)

First Nations Child and Family Caring Society of Canada

ISSN

1708-489X (print)

2293-6610 (digital)

Explore this journal

Cite this document

Bennett, M. (2011). Editorial: Exploring Complexities in the Research Involving

First Peoples Children, Families and Communities. First Peoples Child \& Family

Review, 6(1), 5-8. https://doi.org/10.7202/1068892ar viewed online.

https://apropos.erudit.org/en/users/policy-on-use/ 


\section{First Peoples Child \& Family Review}

An Interdisciplinary Journal Honoring the Voices, Perspectives and Knowledges of First Peoples through Research, Critical Analyses, Stories, Standpoints and Media Reviews

Volume 6, Number 1, 2011, p.5-8

\section{Editorial}

\section{Exploring Complexities in the Research Involving First Peoples Children, Families and Communities}

\author{
Marlyn Bennett
}

The lives of First Peoples peoples in Canada are complex. The issues facing individuals who advocate, work and do research with and for Aboriginal populations are complex as well. This issue of the First Peoples Child \& Family Review journal looks at a number of the complicated issues facing First Peoples communities and those that work and do research for and with First Peoples peoples. This issue of the journal is comprised of 8 submissions. The first submission is a poem on new beginnings while the following articles focus on a range of issues relating to the challenges of working in urban Aboriginal communities where poverty is ever present. Important to identity development is the need for culturally restorative measures that are more appropriate when working with Aboriginal children and youth who are transitioning out of care toward adulthood. Equally complicated is working in northern communities where the government continues to rely upon social workers from the South to work with Inuit families. Included among the submissions is an article exploring the institutional aspects of residential schools and how these earlier experiences contribute to the overrepresentation of First Peoples people in the prison and other institutional systems and reflect the social statistics that define the Aboriginal experience in Canada. A focus on bullying and whether children can individually assent to research is also presented in this issue. Bullying is a complex problem for many children, especially aboriginal children, and the solutions for dealing with it are compounded when the bullying happens among children of the same race. More and more researchers want to do research with children however there are ethical considerations around conducting research that involves children. The articles upon which these complex issues highlight are each summarized briefly below.

Challenges faced by staff working with Aboriginal people residing in urban areas that are characterized by high levels of poverty are rarely addressed in the literature. Jason Brown and Cheryl Fraehlich's article, Aboriginal family services agencies in high poverty urban neighborhoods: Challenges experienced by local staff (pp. 10-27) starts off this issue of the journal by examining unique challenges facing three Aboriginal family services agencies operating in the downtown core of one Canadian city which deals with such realities on a day-to-day basis. To get at the heart of understanding these challenges Brown and Fraehlich asked a simple question of 44 individuals employed by these urban agencies. The question was, "what are the challenges of working in your community? Using participatory methods, the authors used the assistance of the participants in analyzing the responses. The participants' responses were grouped into twelve clusters on the challenges of working in the community. The participant's responses included: the lack of privacy, the depth of need, how their work affects them personally, maintaining healthy boundaries, knowing how best to be helpful, addressing structural issues, meeting various needs, dealing with substancerelated problems, gang activity, negative outside influences, working with government and working with limited funding. Each of these clustered responses is described and analyzed using bridging indices and comparisons to the available literature. We learn Aboriginal communities are in desperate need of a full range of family services to address real community and family healing but typically face funding discrepancies and inequitable political and social treatment. 


\section{Editorial}

In addition to these inequalities, the challenges facing employees working in poor urban areas typically include poor housing, few educational and employment opportunities as well as social segregation. These challenges in turn lead to stress and burnout by staff because the funding provided does not adequately assist in treating the symptoms of crime, substance use and/or the structural inequality, which typically arise, from oppression and the disadvantaged position of Aboriginal people generally in Canadian society. Challenges experienced by Aboriginal employees working with Aboriginal families in an urban context are rarely addressed in the literature and the authors advocate for further exploration of these issues as well as the need to change the inequitable funding arrangements that continue to disadvantage urban Aboriginal families and the staff vesting in working with them.

Developing a culturally restorative approach to Aboriginal child and youth development: Transitions to adulthood, by Estelle Simard and Shannon Blight (pp. 28-55) extolls on the importance of culturally restorative practices as a developmental tool that can assist children and youth in care in developing and recapturing their rightful identifies as Aboriginal adults. Culturally restorative practice, as explained by Simard and Blight, is based on work by the Weechi-It-Te-Win Family Services that build upon the sacredness of cultural teachings by careful reflecting on the family and the community's natural protection networks. The paper reviews the literature on culturally relevant interventions and approaches to service provision that are geared toward development achievements for Aboriginal youth. The themes of Aboriginal development within the context of Aboriginal worldviews, cultural structures, cultural attachment, identity development, the sacredness of relationships and most importantly developmental achievements are explored.

A brief review of the genesis behind the development of residential schools is provided by Julia Rand's in Residential schools: Creating and continuing institutionalization among Aboriginal peoples in Canada (pp. 56.65). While the coverage of this phenomena is not new, it helps readers to consider the ideology behind why these schools developed they way they did. Rand demonstrates the association between First peoples' experiences in residential school and subsequent institutionalization of Aboriginal people in other Canadian systems beyond the residential school era. In trying to understand why Aboriginal people are overrepresented across many institutionalized systems, Rand analyzed the notion of Total Institutions developed by Erving Goffman (a Canadian-born sociologist and writer). The objective of the Total Institutions is to destroy a person's ability to fully achieve selfhood and exercise autonomy over their life and their cultural identity. Residential schools utilized this approach by first stripping children of their identity, clothing, and possessions and then by subjecting them to extreme cleansing, disinfecting, and haircuts and issuing identifications numbers rather than addressing them by the names given to them by their families. Secondly, the child's social and cultural structures inside and outside of residential schools were altered significantly through segregation from both sibling members inside and families and communities outside the school. The Total Institutional approach produced individuals who experienced a complete loss of identity in themselves. This also resulted in lost relationships with family outside residential schools and diminished perceptions about their own abilities to exercise personal agency over their actions important for decisionmaking. Ultimately, Rand posits, that, such an approach made it difficult for many children to function effectively outside of this authoritarian environment. As a result, many Aboriginal people have gravitated toward similar environments upon leaving residential care. This tendency to gravitate toward the familiar provides one explanation as to why residential schools survivors might be found in disproportionate numbers in various types of institutions (i.e. such as correctional institutions) including overrepresentation in the statistics related to family violence, battered women's shelters, and the child welfare system.

In Stuck in the ways of the south: How meritocracy, bureaucracy, and a one-size-fits-all approach to child welfare fails Nunavut's children (pp. 66-82), Patricia Johnston examines the efficacy in the way the Nunavut government is meeting responsibilities in servicing and protecting Inuit children, youth and families in the north. The author wrote this article in response to public opinion that played out in the media regarding problem areas identified by the Auditor General in an evaluation report regarding child, youth and family services in Nunavut and the need to address staffing shortages in the social work field. In particular, Johnston questions the government's approach of consistently relying upon the hiring of Quallunaat (non-Inuit) social workers that are educated in southern universities who then, in turn, enforce southern values and expectations on Inuit children and families. Furthermore, Johnston contends that modeling 
a northern child welfare system premised on southern values and education continues to maintain a colonial structure that has been in place for too long. Inuit people were characterized as having neither the education nor the merit for holding executive and/or senior management positions within government, particularly as it relates to child welfare services despite the Nunavut government's target of employing 53\% Inuit by 2012. The lack of Inuit social workers reflects "new racism" within the Government of Nunavut because it continually places high value on the principles of individual achievement and meritocracy. This approach, Johnston says, continues to protect white privilege and leaves minority groups disadvantaged and employed in subordinate positions. She notes that education in the north remains mainstream despite the fact that it incorporates First Nations context into the curriculum however this context does not fit crossculturally in an Inuit context. Through interviews with Quallunaat and Inuit social workers in the territory, Johnston demonstrates how the Government of Nunavut has failed to protect Inuit children and in the process has continued to marginalize Inuit people who are overlooked and viewed as incapable of holding positions related to directors, managers and supervisors. The overall result is a child welfare system that lacks cultural relevance to the Inuit.

The next article moves to bullying issues among children and youth in Australia. Written by Juli Coffin, "Make them stop it": What Aboriginal children and youth in Australia are saying about bullying (pp. 83-98), explores and summarizes a three year research program that contextualizes bullying in an Aboriginal cultural environment. Research was conducted among 140 children and youth from three locations within the Yamaji region of western Australia. The author worked with an Aboriginal steering group to conduct and pilot an interview guide and utilized Aboriginal research assistants to conduct interviews and focus groups with children and youth. The responses were analyzed and shared with the schools and communities in these three regions. The results shed light on the frequency, language and feelings associated with bullying. What, why, where does bullying occur and who do children and youth go to when they want to tell someone about bullying and more importantly what children and youth want done about bullying. One major unique finding that resulted from this study centers on the intra- rather than inter-racial aspects of bullying. Aboriginal children and youth tend to be bullied by other Aboriginal children and youth and that this type of bullying tends to hurt more than inter-racial bullying. The children shared that they felt particularly threatened inter-racially when they entered another Aboriginal community or school. Better clothing and or scholarly accolades were cited as some of the factors that have led to jealousy, which is often expressed through aggression and bullying. Addressing this type of bullying will requires commitment to building strong/positive racial identity among children and youth about their Aboriginality and addressing the factors around inequality that exist among and between some of the Aboriginal communities.

"Why do I need to sign it? Issues in carrying out child assent in school-based prevention research within a First Nation community (pp. 99-113), by Lola Baydala, Sherry Letendre and Lia Ruttan, Stephanie Worrell, Fay Fletcher, Liz Letendre and Tanja Schramm, focuses on unique ethical challenges around the involvement of First Nations children in research initiatives. Research for a community-based evaluation of a cultural program (Nimi Icinohabi) delivered to young children and youth in grades 3, 4, 7 and 8 was conducted in the Alexis Nakota Sioux community in western Canada. At issue is the ethical rules around child assent which are based on western notions of what is ethical however it was determined that culturally, from an Aboriginal perspective, the ethical rules around child assent were viewed as particularly inappropriate within the community in which this research took place. The challenges relate to obtaining the free and informed consent of parents and guardians in order to involve children in research. Informed consent in research with children involves two parts: parental consent and child assent. The authors explain that parental consent refers to a parent or guardian's informed consent to allow the researcher to ask the child if they agree to participate in research; their agreement is called child assent. Baydala and her colleagues further note that in cases where consent is received from the parent or guardian but the child does not give asset, the child's wishes are respected and research is or is not carried out based on the individual child's wishes. It was noted that asking children to make a decision that rightfully belonged with the whole community to decide was not appropriate. The Elders in this community viewed child assent as giving children adult responsibilities before they are ready to take them on. The western practice of obtaining child assent was viewed as role reversal that can jeopardize families and contribute to increased child welfare involvement, and ultimately affects the family's 


\section{Editorial}

kinship responsibility, respect and well-being. It was found that child assent procedures based on western ethics emphasizes individualism which conflicts with community norms that center on the community's collective responsibility for children. This was seen as disrespectful of the collective norms of the community. The elders note that such practices put children and youth in culturally unsafe positions and goes against the grain of the community's ethics. Community norms are in place to protect children. The decision was that ethical processes premised on western ideology should not continue to contribute to the undermining of community and cultural norms. To do so is to replicate and reinforce colonial systems that have done great harm to Aboriginal families in the past.

We end the journal by looking at issues that impact on Aboriginal youth in care. Cannabis use among Aboriginal youth in the non-Aboriginal protection services system (pp. 114-125) explored the risky behaviour between Aboriginal and non-Aboriginal youth in care in the Province of Ontario. Youth participants between the ages of 14 and 17 were randomly drawn from three child protection agencies. This particular age group was targeted primarily because the researchers could maximize the measurement of adolescent health risk behaviours associated with substance use. The researchers indicate that the youth who identify as Aboriginal did not differ from non-Aboriginal youth, on their report of lifetime specific child maltreatment types, nor on their exposure to intimate partner violence. Aboriginal youth also scored similarly with non-Aboriginal youth on the physical abuse subscale; the sexual abuse scale; the emotional neglect scale as well as the physical neglect scale. However the study reveals the importance of building strong relationships between youth and caregivers. The data reveals that Aboriginal youth who report negative identification with their caseworker were five times as likely to use cannabis in the past 12 months compared to Aboriginal youth who reported a more positive relationship with their caseworkers. Having a positive relationship with your caseworker is identified as being a protective factor in regarding to abstaining from cannabis use among Aboriginal and non-Aboriginal youth in the child welfare system. The implications of this study center on considering caseworkers as potential attachment figures that might be helpful in stemming the use of cannabis among Aboriginal youth and salient to understanding the outcomes of Aboriginal youth.

Of course the answers to the issues and questioned identified in each of these articles are not easy but the articles evidence that there are solutions to these complex issues. They are rooted in cultural approaches that are restorative and protective in purpose. These ways of being recognize the importance of relationship building within our communities and among our allies and the importance of identity in building individuals who take strength from their cultural roots and First Peoples' identity. These articles do not answer all the complexities facing First Peoples families and communities but they bring us closer to examining the past and current realities for answers about what is possible for the future. 